\title{
Uji Aktivitas Antioksidan dan Fenolik Total Fraksi Etil Asetat Daun Sembung (Blumea balsamifera (L.) DC)
}

\author{
Azimatur Rahmi ${ }^{1}$, Tika Afriani ${ }^{*}{ }^{*}$, Linda Hevira ${ }^{1}$, Wike Widiawati ${ }^{1}$ \\ ${ }^{1}$ Program Studi Farmasi, Universitas Mohammad Natsir, Bukittinggi, Sumatra Barat, Indonesia
}

\author{
Corresponding Author: \\ Tika Afriani \\ tika.afriani91@gmail.com \\ Received: February 2021 \\ Accepted: June 2021 \\ Published: September 2021 \\ CTika Afriani et al. This is an \\ open-access article \\ distributed under the terms \\ of the Creative Commons \\ Attribution License, which \\ permits unrestricted use, \\ distribution, and \\ reproduction in any medium, \\ provided the original author \\ and source are credited.
}

\begin{abstract}
The aim of this study is to investigate antioxidant activity and total phenolic content of ethyl acetate fraction of Sembung leaves. Sembung (Blumea balsamifera L.) is a plant that has the potential as an antioxidant because it contains secondary metabolites of alkaloids, steroids, flavonoids, saponins, and phenolic compounds. In this study, antioxidant activity was tested by using 1,1-diphenyl-2-picrylhydrazyl (DPPH) for free radical scavenging activity assay. Evaluation of total phenolic content was tested by using the Folin-Ciocalteau method. The results showed that the ethyl acetate fraction of Sembung leaves possess showed medium antioxidant activity with IC 50 value of 221.821 compare with reference standard ascorbic acid with IC 50 value $68.25 \mathrm{ppm}$. The ethyl acetate fraction of Sembung leaves has a total phenolic content of $161.101 \mathrm{mg}$ GAE/g. This study provided that Blumea balsamifera leaves possess antioxidant.
\end{abstract}

Keywords: Blumea balsamifera leaves, antioxidant, DPPH, total phenolic

\section{Pendahuluan}

Radikal bebas merupakan suatu molekul, atom yang mempunyai satu atau lebih elektron tidak berpasangan pada orbital terluarnya, sehingga elektron tersebut sangat reaktif mencari pasangan dengan mengikat elektron molekul lain yang berada disekitarnya ${ }^{[1],[2]}$. Biasanya elektron radikal tersebut dapat merusak makro molekul yang berperan dalam pembentukan sel seperti protein, karbohidrat, lemak dan DNA ${ }^{[3]}$. Radikal bebas berasal dari dalam tubuh sebagai bagian dari hasil proses metabolisme dan dari luar tubuh dapat disebabkan oleh faktor lingkungan, termasuk kebiasaan merokok, penggunaan pestisida, polusi dan radiasi ${ }^{[4]}$.
Biasanya sel normal mampu melawan efek kerusakan tersebut melalui enzim antioksidan primer, misalnya superoxide dismutase atau catalase $^{[5]}$, serta sistem pertahanan alami pada tubuh manusia dapat menetralisir radikal bebas namun tidak mampu menetralisir radikal bebas dalam jumlah yang besar. Oleh karena itu, tubuh membutuhkan substansi penting yang membantu melindungi tubuh terhadap serangan dari radikal bebas ${ }^{[6]}$.

Beberapa penelitian mengungkapkan bahwa senyawa radikal yang dihasilkan dari reaksi oksidasi dapat di tangkal apabila dia bereaksi dengan antioksidan membentuk molekul yang stabil dan tidak berbahaya[6]. Sehingga senyawa Antioksidan sangat berperan dalam membantu 
mengatasi kerusakan oksidatif akibat radikal bebas atau senyawa oksigen reaktif ${ }^{[7]}$. Senyawa antioksidan terdiri dari antioksidan endogen yang diproduksi oleh tubuh dan eksogen yang berasal dari asupan dari luar, seperti suplemen antioksidan serta asupan makanan yang mengandung antioksidan alami. Aktifitas senyawa antioksidan dapat dilihat berdasarkan tingkat hambatan inhibition concentration (IC50) untuk menghambat radikal bebas. Semakin banyak radikal bebas yang dihambat oleh antioksidan, maka semakin kecil $\mathrm{IC}_{50}{ }^{[8]}$. Sumber senyawa antioksidan alami banyak terdapat pada sayuran, buah-buahan, rempah-rempah dan tanaman obat lainnya ${ }^{[9]}$. Biasanya pada tumbuh-tumbuhan tersebut terdapat senyawa kimia metabolit sekunder golongan senyawa turunan fenol seperti flavonoid, kumarin, tokoferol dan asam organik[3],[10]. Salah satu tumbuhan yang berpotensi sebagai antioksidan adalah Sembung (Blumea balsamifera (L.) DC). Beberapa penelitian menunjukkan ekstrak daun Sembung memiliki aktivitas biologis sebagai antiinflamasi, antikanker, antioksidan dan antimikroba[11]. Sembung (Blumea balsamifera (L.) DC) termasuk famili Asteraceae dan genus Blumea.

Tanaman Sembung memiliki kandungan zat aktif yaitu minyak atsiri 0.5\% (sineol, borneol, landerol, dan kamper), flavanol, tanin, damar dan ksantoksilin' ${ }^{[2],[13]}$. Penelitian sebelumnya melaporkan bahwa daun Sembung mengandung senyawa metabolit sekunder golongan alkaloid, steroid, flavonoid, saponin dan fenolik. Beberapa khasiat yang diketahui dari daun Sembung diantaranya untuk mengobati beri-beri, eksim, sakit pinggang, dermatitis, rematik, cedera kulit ${ }^{[12]}$, antimikroba, antiinflamasi[14], penyembuhan luka dan antioksidan ${ }^{[15]}$. Pemanfaatan tanaman Sembung sebagai obat tradisional terutama pada bagian daunnya. Di negara-negara Asia Tenggara seperti Malaysia, Thailand, Vietnam, Pilipina dan China, tumbuhan ini digunakan untuk mengobati eksim, dermatitis, beriberi, lumbago, rematik dan kerusakan kulit. Sedangkan sebagian masyarakat Indonesia memanfaatkan daun Sembung (Blumea balsamifera L) untuk meredakan nyeri haid, flu, demam, asma, sariawan, diabetes, batuk dan diare ${ }^{[16]}$.
Sebagian peneliti telah ada yang melaporkan bagaimana aktivitas antioksidan dari tanaman Sembung ini diantaranya Kusumawati et al, 2016 ${ }^{[17]}$ dari lolohan daun Sembung, dan Mantra et al, 2019[18] tentang karakterisasi senyawa bioaktif daun Sembung, dimana sampel daun yang diambil berasal dari Pulau Bali. Berdasarkan literatur penelitian tentang aktifitas daun Sembung ini belum ada yang dilaporkan dari daerah Sumatra, hal ini menjadi pertimbangan karena pengaruh lokasi tumbuh serta unsur hara yang terkandung di dalam tanah dapat mempengaruhi komposisi serta efektifitas dari senyawa metabolit yang terdapat pada suatu tanaman[19],[20].

Tujuan dari penelitian ini adalah untuk melihat bagaimana aktivitas antioksidan dan kadar fenolik total, dari daun Sembung (Blumea balsamifera L.) yang tumbuh di daerah Sumatra Barat. Korelasi dengan hasil aktivitas yang telah dilaporkan sebelumnya. Pengujian aktivitas ini akan dilihat dari fraksi mana yang banyak mengandung senyawa metabolit sekunder dari uji pendahuluan secara skrining fitokimia. Kemudian akan dilihat juga bagaimana kandungan fenolik dari sampel daun tersebut dan hubungannya dengan aktivitas antioksidan. Penetapan kadar fenolat total dipilih dengan menggunakan metoda Folin-Ciocalteau, karena metoda ini sederhana, cepat, murah namun memiliki reliabilitas yang tinggi. Reagen FolinCiocalteau merupakan oksidator senyawa fenolik di dalam sampel untuk menghasilkan kompleks warna biru yang diukur intensitasnya dengan spektrofotometer sinar tampak[21]. Sedangkan pengujian aktivitas antioksidan menggunakan metode serapan radikal bebas DPPH. Pemilihan metoda ini dikarenakan tidak membutuhkan banyak reagen, cepat dan sederhana ${ }^{[22]}$.

\section{Metodologi Penelitian}

\section{Bahan kimia}

Bahan-bahan yang digunakan pada penelitian ini 1,1-diphenyl-2-picrylhidrazyl (DPPH) p.a, etanol 96\%, akuades, asam sulfat pekat, amoniak, kloroform, asam galat (Merck), reagen Folin Ciocalteau, natrium karbonat, $n$-heksan, etil asetat, asam askorbat (Merck). 


\section{Peralatan}

Alat-alat yang digunakan dalam penelitian ini adalah satu set alat spektrofotometer UV-Vis (Shimadzu serial No. A116355 corp 81034), rotary evaporator (Dlab), timbangan analitik (KERN ABJ-NM/A135-N), bejana maserasi, corong pisah, alat gelas (Iwaki), pipet volum, tabung reaksi (Iwaki), kaca arloji, vial, spatel, pipet tetes, kertas saring, aluminium foil.

\section{Prosedur penelitian}

\section{Persiapan sampel}

Sampel yang digunakan pada penelitian ini adalah daun Sembung (Blumea balsamifera) yang diperoleh di Kecamatan Kinali Barisan, Kabupaten Pasaman Barat. Identifikasi tanaman dilakukan oleh Dr. Nurainas di Herbarium Andalas, Jurusan Biologi FMIPA, Universitas Andalas, Padang, Sumatra Barat.

\section{Ekstraksi dan fraksinasi}

Untuk mendapatkan ekstrak sampel, sebanyak 3,000 g daun Sembung segar dibersihkan dari kotoran lalu dirajang dan dikering anginkan. Selanjutnya simplisia dimaserasi menggunakan etanol 96\% selama 24 jam kemudian disaring hingga diperoleh ampas dan filtrat. Ampas dimaserasi kembali dengan etanol 96\% seperti perlakuan pertama hingga tiga kali pengulangan. Filtrat yang diperoleh kemudian diuapkan dengan rotary evaporator sehingga diperoleh ekstrak kental etanol.

Ekstrak etanol daun Sembung (Blumea balsamifera L.) dipartisi dengan pelarut etanol dan n-heksan (150 mL : $150 \mathrm{~mL}$ ) di dalam corong pisah. Lapisan n-heksan (bagian atas) disisihkan. Lapisan etanol (bagian bawah) dipartisi kembali menggunakan n-heksan dengan perbandingan yang sama, tahapan ini diulang hingga warna larutan menjadi jernih. Fraksi n-heksan yang didapat dipekatkan menggunakan rotary evaporator, lapisan etanol dilanjutkan dengan partisi tahap akhir menggunakan etil asetat dengan perbandingan $100 \mathrm{~mL}$ sisa air : $60 \mathrm{~mL}$ air : $100 \mathrm{~mL}$ etil asetat. Tahapan ini diulang hingga warna larutan menjadi jernih. Fraksi etil asetat yang diperoleh digabungkan lalu dipekatkan menggunakan rotary evaporator.

\section{Skrining fitokimia ${ }^{[23]}$}

Untuk penapisan fitokimia meliputi uji alkaloid, flavonoid, fenolik, saponin, steroid dan terpenoid.

\section{Uji alkaloid}

Sebanyak $1 \mathrm{~mL}$ fraksi n-heksan, etil asetat dan sisa air masing-masingnya ditambahkan $2 \mathrm{~mL}$ kloroform, $2 \mathrm{~mL}$ amoniak dan 5 tetes $\mathrm{H}_{2} \mathrm{SO}_{4}$ pekat kemudian dikocok hingga terbentuk dua lapisan. Lapisan atas ditambahkan dengan pereaksi mayer. Terbentuknya endapan putih menunjukkan bahwa sampel positif mengandung alkaloid.

\section{Uji flavonoid}

Sebanyak $2 \mathrm{~mL}$ fraksi n-heksan, etil asetat dan sisa air masing-masingnya dipanaskan selama 5 menit. Kemudian ditambahkan $0.05 \mathrm{~g}$ serbuk

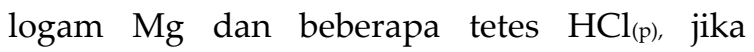
terbentuk warna kuning-orange sampai merah, menunjukkan adanya senyawa flavonoid.

\section{Uji fenolik}

Sebanyak $1 \mathrm{~mL}$ fraksi n-heksan, etil asetat dan sisa air masing-masingnya ditambahkan dengan 10 tetes $\mathrm{FeCl}_{3}$. Terbentuknya warna hijau kehitaman atau biru kehitaman menunjukkan sampel positif mengandung fenolik.

\section{Uji saponin}

Sebanyak $1 \mathrm{~mL}$ fraksi n-heksan, etil asetat dan sisa air masing-masingnya ditambahkan $10 \mathrm{~mL}$ akuades dikocok selama 1 menit sampai terbentuk busa. Ditambahkan 2 tetes $\mathrm{HCl}$ pekat, jika busa tidak hilang selama 7 menit, maka sampel positif mengandung saponin.

\section{Uji steroid dan triterpenoid}

Sebanyak $1 \mathrm{~mL}$ fraksi n-heksan, etil asetat dan sisa air masing-masingnya diletakkan pada plat tetes ditambahkan dengan asam asetat anhidrat dan $\mathrm{H}_{2} \mathrm{SO}_{4}$. Jika terbentuk warna biru atau hijau sampel positif mengandung steroid, sedangkan 
triterpenoid menghasilkan warna kecoklatan atau ungu.

\section{Profil kromatografi senyawa aktif antioksidan $^{[24]}$}

Setiap fraksi daun Sembung ditotolkan pada plat KLT kemudian dielusi menggunakan eluen n-heksan : etil asetat (1:2) dan diamati pada sinar UV $254 \mathrm{~nm}$ dan $366 \mathrm{~nm}$. Perubahan warna noda menjadi kuning pucat setelah disemprot larutan DPPH menunjukkan adanya aktivitas antioksidan ${ }^{[22] .}$

\section{Uji aktivitas antioksidan ${ }^{[23]}$}

\section{Pembuatan larutan DPPH}

Sebanyak 5 mg DPPH dilarutkan dengan etanol $96 \%$ dalam labu ukur 50 mL. Kemudian dibuat larutan dengan konsentrasi 35 ppm.

Penentuan panjang gelombang maksimum

Sebanyak $3.8 \mathrm{~mL}$ larutan DPPH 35 ppm ditambahkan dengan $0.2 \mathrm{~mL}$ etanol $96 \%$ dalam tabung reaksi. Dibiarkan selama 30 menit di tempat yang gelap. Serapan larutan diukur dengan spektrofotometer UV-Vis pada panjang gelombang 400-600 nm. Tentukan panjang gelombang maksimum.

\section{Pembuatan larutan uji}

Larutan uji dari fraksi etil asetat daun Sembung dibuat larutan induk dengan konsentrasi 100 ppm, kemudian disiapkan larutan uji dengan konsentrasi (20 ppm, 40 ppm, 60 ppm, 80 ppm dan 100 ppm). Sebagai kontrol untuk pembanding digunakan vitamin C (20 ppm, 40 ppm, 60 ppm, 80 ppm dan 100 ppm) dalam akuades.

\section{Uji aktivitas antioksidan}

Larutan uji dipipet masing-masing $0.2 \mathrm{~mL}$, ditambahkan $3.8 \mathrm{~mL}$ larutan DPPH $35 \mathrm{ppm}$ diamkan selama 30 menit pada ruangan gelap dengan suhu $30{ }^{\circ} \mathrm{C}$. Kemudian diukur serapan dengan panjang gelombang maksimum pada rentang 515-520 $\mathrm{nm}^{[24]}$. Masing-masing dilakukan 3 kali pengulangan. Persen peredaman radikal bebas dari masing-masing konsentrasi dihitung dengan rumus:

$$
\% \text { inhibisi }=\frac{\mathrm{A} 1-\mathrm{A} 2}{\mathrm{~A} 1} \times 100 \%
$$

\section{A1: absorbansi kontrol \\ A2: absorbansi sampel}

\section{Penetapan kadar fenolik total ${ }^{[25]}$}

Penentuan panjang gelombang maksimum

Sebanyak $10 \mathrm{mg}$ asam galat dilarutkan dengan etanol 96\% dalam labu ukur $100 \mathrm{~mL}$, ditambahkan $1 \mathrm{~mL}$ etanol kemudian tambahkan akuades sampai tanda batas sehingga diperoleh larutan induk asam galat $100 \mathrm{ppm}$. Pipet $1 \mathrm{~mL}$ larutan induk asam galat 100 ppm dan masukkan ke dalam labu takar $10 \mathrm{~mL}$. Ditambahkan $1 \mathrm{~mL}$ pereaksi Folin-Ciocalteau lalu dikocok hingga homogen biarkan selama 8 menit. Kemudian ditambahkan $4 \mathrm{~mL} \mathrm{Na}_{2} \mathrm{CO}_{3}$ 7\%, diamkan pada suhu kamar selama 15 menit. Ukur serapan pada panjang gelombang 700 hingga $800 \mathrm{~nm}$ untuk penentuan panjang gelombang maksimum.

\section{Pembuatan kurva kalibrasi}

Larutan induk asam galat 100 ppm dipipet masing-masing 1, 3, 5, 7 dan $9 \mathrm{~mL}$, cukupkan dengan akuades hingga $10 \mathrm{~mL}$, sehingga diperoleh konsentrasi 10, 30, 50, 70 dan 90 ppm. Masing-masing konsentrasi dipipet $0.2 \mathrm{~mL}$ dalam labu ukur $10 \mathrm{~mL}$, tambahkan reagen Folin-Ciocalteau $1 \mathrm{~mL}$, kocok dan dibiarkan 8 menit. Tambahkan $3 \mathrm{~mL}$ larutan $\mathrm{Na}_{2} \mathrm{CO}_{3} 7 \%$ kocok homogen diamkan selama 2 jam pada suhu ruang. Ukur serapan pada panjang gelombang maksimum, lalu buat kurva kalibrasi hubungan antara konsentrasi asam galat (ppm) dengan absorban.

\section{Penetapan kadar fenolik total}

Sebanyak $5 \mathrm{mg}$ fraksi etil asetat daun Sembung dilarutkan dengan etanol 96\% dalam labu ukur $50 \mathrm{ml}$ sehingga diperoleh larutan dengan konsentrasi $100 \mathrm{ppm}$. Pipet $0.2 \mathrm{ml}$ larutan fraksi etil asetat $100 \mathrm{ppm}$, tambahkan $1 \mathrm{ml}$ reagen Folin-Ciocalteau, kocok dan dibiarkan 4-8 menit. Tambahkan $3 \mathrm{ml}$ larutan $\mathrm{Na}_{2} \mathrm{CO}_{3} 7 \%$ hingga homogen diamkan selama 2 jam pada suhu ruang. Ukur serapan pada panjang gelombang maksimumnya. 


\section{Hasil dan Diskusi}

Pengambilan sampel daun tanaman Sembung yang diperoleh dari Kecamatan Kinali Barisan, Kabupaten Pasaman Barat dimana secara geografis terletak pada dataran rendah dan telah diidentifikasi di Herbarium Andalas, Jurusan Biologi, Fakultas Matematika dan Ilmu Pengetahuan Alam, Universitas Andalas dengan spesies Blumea balsamifera (L.) DC yang termasuk dalam famili Asteraceae.

Metode ekstraksi yang digunakan adalah metode maserasi atau perendaman, dimana metode ini tidak merusak komponen kimia pada sampel karena tidak adanya pemanasan dalam proses ekstraksi[24]. Ekstrak kental etanol yang diperoleh sebanyak $72 \mathrm{~g}$ dengan rendemen sebesar $11.07 \%$. Jika dibandingkan dengan rendemen ekstrak kental yang terdapat pada Farmakope Herbal nilainya adalah tidak kurang dari $10.6 \%$. Artinya hasil rendemen ekstrak etanol telah memenuhi standar yang terdapat dalam Farmakope Herbal.

Ekstrak kental yang dihasilkan kemudian difraksinasi dengan pelarut yang berbeda tingkat kepolarannya yaitu pelarut n-heksan, etil asetat, dan air sehingga diperoleh hasil fraksi berupa fraksi n-heksan, fraksi etil asetat, dan fraksi sisa air berturut-turut $2.14 \mathrm{~g}, 5.03 \mathrm{~g}$, dan $6.7 \mathrm{~g}$.

Fraksi n-heksan, etil asetat, dan sisa air daun Sembung dianalisis kandungan senyawa kimianya secara kualitatif menggunakan beberapa pereaksi. Uji ini dilakukan untuk mengetahui metabolit sekunder yang terkandung di dalam daun Sembung. Hasil yang diperoleh dapat dilihat pada Tabel 1 .

Dari hasil skrining fitokimia yang telah dilakukan terlihat fraksi etil asetat positif mengandung seyawa fenolik, alkaloid, dan flavonoid dan negatif mengandung saponin. Fraksi n-heksan hanya positif mengandung senyawa steroid, sedangkan pada sisa air hanya positif mengandung senyawa saponin. Berdasarkan hasil pengujian skrining fitokimia, fraksi etil asetat lebih banyak mengandung senyawa metabolit sekunder dibandingkan dengan fraksi n-heksan dan sisa air. Oleh karena itu pengujian antioksidan dan fenolik total hanya dilakukan pada fraksi etil asetat saja.

Pengujian aktivitas antioksidan pada fraksi melalui profil kromatografi dengan menggunakan DPPH. Hasil positif adanya aktivitas antioksidan dari fraksi tersebut ditandai dengan perubahan warna bercak noda pada plat dari ungu menjadi kuning pucat setelah disemprot dengan. DPPH merupakan radikal bebas yang tidak stabil karena terdapat elektron yang tidak berpasangan. Pemucatan warna DPPH mencerminkan sejumlah elektron yang ditangkap oleh radikal DPPH[26].

Keberadaan senyawa antioksidan dalam suatu bahan dapat dideteksi dengan melakukan uji aktivitas antioksidan. Aktivitas antioksidan merupakan kemampuan suatu senyawa untuk menghambat reaksi oksidasi yang dapat dinyatakan dengan persen penghambatan.

Tabel 1. Hasil uji skrining fitokimia fraksi daun Sembung

\begin{tabular}{llccc}
\hline No & Metabolit Sekunder & Fraksi n-Heksan & Fraksi Etil Asetat & Fraksi Sisa Air \\
\hline 1 & Alkaloid & - & + & - \\
2 & Flavonoid & - & + & - \\
3 & Fenolik & - & + & - \\
4 & Saponin & - & - & - \\
5 & Steroid \& Triterpenoid & + & - & \\
\hline \multicolumn{7}{c}{ Keterangan } & $:(+)=$ Adanya senyawa \\
& & $(-)=$ Tidak ada senyawa
\end{tabular}


Parameter yang digunakan untuk menunjukkan aktivitas antioksidan adalah Inhibition Concentration ( $\left.\mathrm{IC}_{50}\right)$ yaitu konsentrasi suatu zat antioksidan yang dapat menghambat reaksi radikal bebas DPPH sebesar 50\%. Zat yang mempunyai aktivitas antioksidan tinggi, akan memberikan nilai IC 50 yang rendah ${ }^{[9]}$.

Pengujian aktivitas antioksidan terhadap fraksi etil asetat daun Sembung dilakukan dengan metode DPPH dikarenakan merupakan metode yang memerlukan waktu yang singkat dan mudah dilakukan. Prinsip dari metode ini adalah pengukuran penangkapan radikal bebas DPPH oleh suatu senyawa yang memiliki aktivitas antioksidan dengan menggunakan Spektrofotometer UV-Vis sehingga akan diperoleh nilai aktivitas peredaman radikal bebas yang dinyatakan sebagai $\mathrm{IC}_{50}$. Untuk menentukan nilai $\mathrm{IC}_{50}$ dibuat persamaan regresi linear antara konsentrasi (ppm) sebagai absis (sumbu $x$ ) dan nilai \% inhibisi (\%) sebagai koordinatnya (sumbu y). Semakin kecil nilai IC 50 yang diperoleh berarti semakin tinggi aktivitas antioksidan ${ }^{[9]}$.

Dari hasil penelitian uji aktivitas antioksidan fraksi etil asetat daun Sembung didapatkan nilai IC50 sebesar 221.821 ppm sedangkan vitamin C sebagai standar didapatkan nilai IC S0 $_{50} 68.23$ ppm (Tabel 2). Berdasarkan nilai $\mathrm{IC}_{50}$ menunjukkan bahwa fraksi etil asetat daun Sembung memiliki potensi antioksidan kategori sedang, tetapi masih rendah dibandingkan vitamin $C$ sebagai standar. Aktivitas antioksidan pada penelitian ini lebih tinggi dibandingkan dengan penelitian Maslahat et al, 2013[9] pada air rebusan daun Sembung yang memiliki aktivitas antioksidan lemah dengan nilai IC50 293.80 ppm. Hal ini dapat disebabkan oleh perbedaan pelarut yang digunakan dimana komponen bioaktif sampel lebih banyak terlarut pada fraksi etil asetat dibandingkan dalam air. Lokasi pengambilan sampel juga menjadi faktor perbedaan aktivitas antioksidan yang diperoleh, sesuai dengan penelitian Aminah et al, 2016[27] perbedaan daerah tempat pengambilan sampel yang digunakan memiliki tingkat antioksidan yang berbeda. Kadar suatu senyawa dalam tanaman dipengaruhi oleh letak geografis tanaman, faktor iklim yang meliputi suhu, udara dan kelembapan, faktor esensial seperti cahaya, air dan unsur hara tanah. Selain itu kandungan fenolik total dan flavonoid juga mempengaruhi aktivitas antioksidan ${ }^{[28]}$.

Penetapan kadar fenolik total menggunakan metode Folin-Ciocalteau, prinsip dari metode ini adalah terbentuknya senyawa komplek berwarna biru. Intensitas warna biru ditentukan oleh banyaknya fenol yang terkandung dalam larutan sampel, semakin besar konsentrasi fenolik dalam sampel maka semakin pekat warna biru yang dihasilkan ${ }^{[29]}$.

Tabel 2. Hasil perhitungan $\mathrm{IC}_{50}$ fraksi etil asetat daun Sembung

\begin{tabular}{cccc}
\hline Konsentrasi (ppm) & $\begin{array}{c}\text { Absorbansi Sampel } \\
(\mathbf{n m})\end{array}$ & \% Inhibisi & IC $_{50}(\mathbf{p p m})$ \\
\hline 20 & 0.703 & 28.63 \\
40 & 0.688 & 30.15 & \\
60 & 0.667 & 32.25 & 221.821 \\
80 & 0.642 & 34.82 & \\
100 & 0.620 & 37.06 \\
\hline
\end{tabular}


Penetapan kadar fenolik total dilakukan menggunakan larutan standar asam galat. Asam galat digunakan sebagai larutan standar karena asam galat merupakan turunan dari asam hidrobenzoat yang tergolong asam fenol sederhana. Asam galat diketahui memiliki reaktivitas yang cukup tinggi terhadap reagen Folin-Ciocalteau dibandingkan denga senyawa fenol lainnya sehingga dapat digunakan sebagai standar dalam penetapan kadar fenolik total[30].

Pembuatan kurva baku asam galat dilakukan sebanyak tiga kali pengulangan dan untuk menentukan kandungan fenolik total digunakan persamaan dengan nilai $r$ terbaik. Nilai $r$ menunjukkan nilai linearitas yaitu korelasi antara konsentrasi dan absorbansi yang dihasilkan. Semakin baik nilai linearitas (nilai $\mathrm{r}=1$ atau mendekati 1) maka korelasi juga semakin baik. Kurva baku asam galat diperoleh dari menghitung regresi linear antara konsentrasi asam galat sebagai $X$ dan absorbansi asam galat sebagai Y. Diperoleh persamaan regresi $\mathrm{y}=0.0071 \mathrm{x}+0.1483$ dan $\mathrm{R}^{2} 0.9997$ (Gambar 1 dan Tabel 3), persamaan yang diperoleh tersebut digunakan dalam penentuan kadar fenolik total sampel.

Dari hasil penelitian diperoleh kadar fenolik total pada fraksi etil asetat daun Sembung adalah $161.101 \mathrm{mg}$ GAE/g (Tabel 4). Kadar fenolik total pada penelitian ini lebih tinggi dari penelitian yang telah dilakukan oleh Halim et al, 2019[30] yaitu $4.39 \mathrm{mg}$ GAE/g dengan metode dan pelarut yang sama. Menurut Borges et al, 2013[31] faktor lingkungan seperti tanah, suhu, dan curah hujan dapat mempengaruhi konsentrasi komponen fenol. Kandungan fenolik total pada penelitian ini jika dibandingkan dengan penelitian lainnya dengan sampel dan pelarut yang sama termasuk cukup tinggi. Hal ini disebabkan pada setiap jenis tumbuhan memiliki kandungan fenolik total yang berbeda antara satu dengan yang lainnya yang dipengaruhi faktor internal maupun faktor eksternal pada tumbuhan. Faktor eksternal yaitu perairan, habitat, musim, jenis makanan yang tersedia dan faktor lingkungan lainnya. Sedangkan faktor internalnya yaitu ukuran, umur tanaman dan faktor biologis lainnya ${ }^{[32]}$.

Menurut Nakiboglu et al, 2007[33] kemampuan penangkapan radikal bebas DPPH sangat dipengaruhi oleh gugus $\mathrm{OH}$ yang terdapat dalam senyawa fenolik. Semakin banyak gugus hidroksil yang tersubstitusi dalam molekul maka kemampuan penangkapan radikal bebasnya semakin kuat karena semakin banyak atom hidrogen yang dapat didonorkan ${ }^{[34]}$. Oleh karena itu, semakin tinggi total fenolik, maka semakin kecil nilai $\mathrm{IC}_{50}$ dan semakin besar aktivitas antioksidannya.

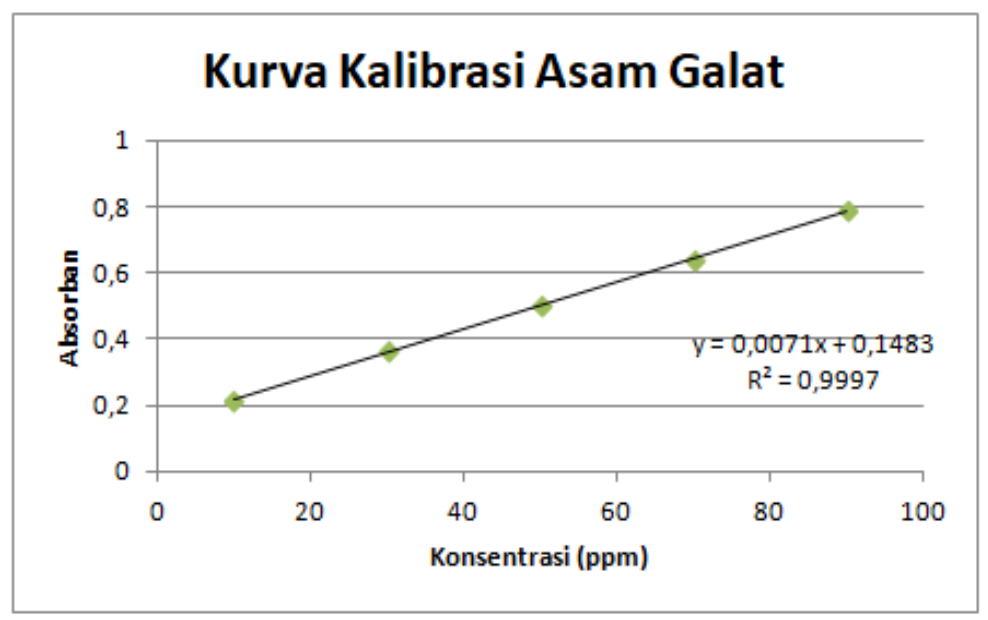

Gambar 1. Kurva kalibrasi asam galat. 
Tabel 3. Hasil Penetapan kadar fenolik total fraksi etil asetat daun Sembung

\begin{tabular}{lcccc}
\hline & $\begin{array}{c}\text { Konsentrasi } \\
\text { Larutan }\end{array}$ & $\begin{array}{c}\text { Absorban } \\
\text { Sampel (nm) }\end{array}$ & $\begin{array}{c}\text { Absorban } \\
\text { Rata-rata (nm) }\end{array}$ & $\begin{array}{c}\text { Kadar } \\
\text { Total Fenol (mg } \\
\text { GAE/g) }\end{array}$ \\
\hline Pengulangan 1 & 100 ppm & 0.273 & & 161.101 \\
Pengulangan 2 & $100 \mathrm{ppm}$ & 0.271 & 0.272 & \\
Pengulangan 3 & $100 \mathrm{ppm}$ & 0.271 & & \\
\hline
\end{tabular}

\section{Kesimpulan}

Penelitian mengenai aktifitas dari daun Sembung ini dapat disimpulkan bahwa fraksi etil asetat daun Sembung (Blumea balsamifera (L.) DC) memiliki aktivitas antioksidan kategori sedang dengan nilai IC $_{50} 221.821$ ppm dengan kadar fenolik total sebesar $161.101 \mathrm{mg} \mathrm{GAE} / \mathrm{g}$.

\section{Ucapan Terima Kasih}

Penulis mengucapkan terima kasih kepada Universitas Mohammad Natsir Bukittinggi dan LL DIKTI wilayah X Surat Keputusan Nomor 1/E1/KPT/2020 tanggal 3 Januari 2020 dan Perjanjian/Kontrak Nomor 086/SP2H/LT/DRPM /2020 tanggal 9 Maret 2020, 083/LL10/PG/2020 tanggal 11 Maret 2020, dan 268/A/UMN/III/2020 tanggal 12 Maret 2020 yang telah memfasilitasi penulis selama proses penelitian.

\section{Daftar Pustaka}

1. Muchtadi, D., Antioksidan dan kiat sehat di usia produktif. Bandung Alfabeta, (2013).

2. Najihudin, A., Chaerunisaa, A. \& Subarnas, A., Aktivitas antioksidan ekstrak dan fraksi kulit batang Trengguli (Cassia fistula L) dengan metode DPPH. Indones. J. Pharm. Sci. Technol., 4(2): 70-78 (2017).

3. Kuntum, K., Menangkal radikal bebas dengan antioksidan. J. Sainstek, 2(2): 183187 (2010).

4. Mbaoji, F. N., Ezike, A. C., Nworu, C. S., Onyeto, C. A., Nwabunike, I. A., Okoli, I. C. \& Akah, P. A., Antioxidant and hepatoprotective potentials of
Stemonocoleus micranthus harms (Fabaceae) stem bark extract. Int. J. Pharm. Pharm. Sci., 8(7): 47-51 (2016).

5. Sarma, A. Das., Mallick, A. R. \& Ghosh, A. $K .$, Free radicals and their role in different clinical conditions: an overview. Int. J. Pharma Sci. Res., 1(3): 185-192 (2010).

6. Toripah, S. S., Abidjulu, J. \& Wehantouw, F., Aktivitas antioksidan dan kandungan total fenolik ekstrak daun kelor (Moringa oleifera LAM). Pharmacon J. Ilm. Farm. UNSRAT, 3(4): 37-43 (2014).

7. Masrifah, M., Rahman, N. \& Abram, P. H., Uji aktivitas antioksidan ekstrak daun dan kulit labu air (Lagenaria siceraria (Molina) Standl.). J. Akad. Kim., 6(2): 98-106 (2017).

8. Wulansari, D. \& Chairul, C., Penapisan aktivitas antioksidan dan beberapa tumbuhan obat Indonesia menggunakan radikal 2,2-diphenyl-1 Picrylhydrazyl (DPPH). Tradit. Med. J., 16(1): 22-25 (2011).

9. Maslahat, M., Nurilmala, F. \& Harpeni, L., Aktivitas antioksidan ekstrak air simplisia daun Sembung (Blumea balsamifera). J. Sains Nat., 3(2): 129-136 (2017.

10. Zerargui, F., Baghiani, A., Khennouf, S. \& Arrar, L., Antioxidant activity assessment of Tamus communis L. Roots. Int. J. Pharm. Pharm. Sci., 8(12): 64-71 (2016).

11. Redha, A., Flavonoid: struktur, sifat antioksidatif dan peranannya dalam sistem biologis. J. Belian, 9(2): 196-202 (2010).

12. Pang, Y., Wang, D., Fan, Z., Chen, X., Yu, F., $\mathrm{Hu}, \quad \mathrm{X} ., \quad$ Wang, K., et al., Blumea balsamifera-A phytochemical and pharmacological review. Molecules, 19(7): 
9453-9477 (2014).

13. Mursito, B., Ramuan tradisional untuk pengobatan jantung. Jakarta Penebar Swadaya, (2002).

14. Nessa, F., Ismail, Z. \& Mohamed, N., Xanthine oxidase inhibitory activities of extracts and flavonoids of the leaves of Blumea balsamifera. Pharm. Biol., 48(12): 1405-1412 (2010).

15. Saewan, N., Koysomboon, S. \& Chantrapromma, K., Anti-tyrosinase and anti-cancer activities of flavonoids from Blumea balsamifera DC. J. Med. Plants Res., 5(6): 1018-1025 (2011).

16. Jumariswan, J., Sari, I., Nursanty, R. \& Suwarno, S., Uji antijamur ekstrak etil asetat daun Sembung (Blumea balsamifera (L) DC) terhadap pertumbuhan jamur Candida albicans resisten flukonazol. Pros. Biot., 5(1): 392-396 (2017).

17. Kusumawati., Wita, I. \& Yogeswara, I. B. A., Antioxidant and antibacterial capacity of Loloh Sembung (Blumea balsamifera) based on extraction method. Maj. Obat Tradis., 21(3): 143-148 (2016).

18. Mantra, I. B. K., Putra, I. N. K. \& Wrasiati, L. P., Karakterisasi senyawa bioaktif ekstrak daun Sembung (Blumea balsamifera (L) DC) dari beberapa jenis pelarut. Media Ilm. Teknol. Pangan, 6(1): 5465 (2019).

19. Astuti, E., Sunarminingsih, R., Jenie, U. A., Mubarika, S. \& Sismindari., Pengaruh lokasi tumbuh, umur tanaman dan variasi jenis destilasi terhadap komposisi senyawa minyak atsiri Rimpang Curcuma mangga produksi beberapa sentra di Yogyakarta. J. People Environ., 21(3): 323-330 (2015).

20. Salim, M., Yahya, Y., Sitorus, H., Ni'mah, T. \& Marini, M., Hubungan kandungan hara tanah dengan produksi senyawa metabolit sekunder pada tanaman duku (Lansium domesticum Corr var Duku) dan potensinya sebagai larvasida. J. Vektor Penyakit, 10(1): 11-18 (2016).

21. Agustiningsih., Wildan, A. \& Mindaningsih., Optimasi cairan penyari pada pembuatan ekstrak daun pandan wangi (Pandanus amaryllifous Roxb) secara maserasi terhadap kadar fenolik dan flavonoid total. J. Ilm. Momentum, 6(2): 3641 (2010).

22. Jami'ah, S. R., Ifaya, M., Pusmarani, J. \& Nurhikma, E., Uji aktivitas antioksidan ekstrak metanol kulit pisang raja (Musa paradisiaca sapientum) dengan metode DPPH (2,2-difenil-1-pikrilhidrazil). J. Mandala Pharmacon Indones., 4(1): 33-38 (2018).

23. Mondong, F. R., Skrining fitokimia dan uji aktivitas antioksidan ekstrak etanol daun Patikan Emas (Euprorbia prunifolia Jacq.) dan bawang laut (Proiphys amboinensis (L.) Herb). J. MIPA, 4(1): 81-87 (2015).

24. Rahman, A., Malik, A. \& Ahmad, A. R., Skrining fitokimia dan uji aktivitas antioksidan ekstrak etanolik buah Buni (Antidesma bunius (L.) Spreng). J. Fitofarmaka Indones., 3(2): 159-163 (2016).

25. Khadijah, K., Jayali, A. M., Umar, S. \& Sasmita, I., Penentuan Total Fenolik Dan Aktivitas Antioksidan Ekstrak Etanolik Daun Samama (Anthocephalus Macrophylus) Asal Ternate, Maluku Utara. J. Kim. Mulawarman, 15(1): 11-18 (2017).

26. Rusli, R., Hardina, M. P., Muflihah, F. \& Rahmadani, A., Profil kromatografi senyawa aktif antioksidan dan antibakteri fraksi n-heksana daun Libo (Ficus variegata Blume). J. Trop. Pharm. Chem., 3(2): 124-130 (2015).

27. Aminah, A., Maryam, S., Baits, M. \& Kalsum, U., Perbandingan aktivitas antioksidan ekstrak etanol daun sirsak (Annona muricata L.) berdasarkan tempat tumbuh dengan metode peredaman DPPH. J. Fitofarmaka Indones., 3(1): 146-150 (2016).

28. Cahyana, H. \& Pratiwi, P., Sintesis ramah lingkungan senyawa imina turunan vanilin dan 2-hidroksi asetofenon serta uji aktivitas biologi dan antioksidan. Pharm. Sci. Res., 2(1): 47-58 (2015).

29. Ismail, J., Runtuwene, M. R. . \& Fatimah, F., Penentuan total fenolik dan uji aktivitas antioksidan pada biji dan kulit buah pinang Yaki (Areca vestiaria Giseke). J. Ilm. Sains, 


$$
\text { 12(2): 84-88 (2012). }
$$

30. Halim, A., Nurlansi, N. \& Nasrudin, N. Analisis Total Fenol Fraksi Etil Asetat Dan Residu Hasil Partisi Ekstrak Etanol Daun Tumbuhan Kaembu-Embu (Blumea balsamifera L.). J. Pendidik. Kim. FKIP Univ. Halu Oleo, 4(1): 13-21 (2019).

31. Borges, L. L., Alves, S. F., Sampaio, B. L., Conceição, E. C., Bara, M. T. F. \& Paula, J. R., Environmental factors affecting the concentration of phenolic compounds in Myrcia tomentosa leaves. Rev. Bras. Farmacogn., 23(2): 230-238 (2013).

32. Malik, A. \& Ahmad, A. R., Determination of phenolic and flavonoid contents of ethanolic extract of Kanunang leaves (Cordia myxa L.). Int. J. PharmTech Res., 7(2): 243-246 (2015).

33. Nakiboglu, M., Urek, R. O., Kayali, H. A. \& Tarhan, L., Antioxidant capacities of endemic Sideritis sipylea and Origanum sipyleum from Turkey. Food Chem., 104(2): 630-635 (2007).

34. Lin, H.-Y., Kuo, Y.-H., Lin, Y.-L. \& Chiang, W., Antioxidative effect and active components from leaves of Lotus (Nelumbo nucifera). J. Agric. Food Chem., 57(15): 6623-6629 (2009). 